\title{
Rethinking of Public Secondary Schools Discipline in Kenya
}

\author{
Erick Nandeke \\ Sammy K. Chumba, PhD \\ Catherine Kiprop, PhD \\ Moi University, School of Education, \\ Department of Education and Policy Studies, Eldoret, Kenya
}

doi: 10.19044/esj.2017.v13n19p156 URL:http://dx.doi.org/10.19044/esj.2017.v13n19p156

\begin{abstract}
Student Council is a representative structure through which students in a secondary school become involved in school affairs. The study set out to investigate student council participation in the management of discipline in public secondary schools in Teso North Sub-County in Busia County, Kenya. The study sought to establish: the influence of student council participation in the formulation of rules and regulations on management of discipline, and the influence of student council involvement in formulating punishment on the management of discipline. The target population was 7379 students and 189 teachers and 27 principals from 27 schools. The research employed descriptive survey design using a random sample of 365 students, 18 teachers and 9 principals. This sample size was determined using Krejcie and Morgan's table of sample determination and using coefficient variation of $30 \%$ and a standard error of $2 \%$ through stratified simple random sampling technique. The data was collected using a selfadministered questionnaire. The study established that schools involved students in designing punishment but students never took punishment positively and that common disciplinary problems experienced in schools was due to lack of students involvement. It was further established that students were haphazardly involved in the school management of students' discipline. Thus the study recommends schools to empower students' council in which students' views and ideas are heard and discussed; Ministry of education to organize and offer seminars where school heads are well sensitized on involving students in school management.
\end{abstract}

Keywords: Counseling, Discipline, Guidance, Student Council and Student Council Participation.1.0 Introduction 
Student participation in management of discipline refers to the work of student representative bodies-such as school council, student parliaments and the prefects' body. It is also a term used to encompass all aspects of school life and decision making where students may make contribution, informally through individual negotiation as well as formally through purposely-created structures and mechanisms. Student participation also refers to participation of students in collective decision - making at school or class level and to dialogue between students and decision makers, not only consultation or a survey among students. Student participation in management is often viewed as problematic to school administrators, parents and society at large. This is often due to the fact that students are viewed as minors, immature and lacking in the expertise and technical knowledge that is needed in the running of a school. Thus student participation in management is often confined to issues concerned with student welfare and not in core governance issues.

As defined by Bäckman and Trafford (2007), the school management represents a wide definition of school leadership, including both instrumental and ideological aspects. Since so many factors cannot be controlled by executive powers alone, an open and democratic approach is the only way to a successful and sustainable leadership in a modern school. However, democratic school governance is not merely a means of survival for the school head; there are other, far more important reasons (Bäckman \& Trafford, 2007).

Existing literature shows that schools in different parts of the world differ on the extent to which they involve students in management. In the United States of America, for instance, Neigel (2006) notes that high school reform efforts strongly recommend that schools model democratic principles and give students, teachers, parents, and community members a significant role in school management and the decision-making process, and this has led to increased participation of students in governance. Most secondary schools in developed countries such as the US, Britain and Germany offer students the opportunity to participate in some sort of student government (Miller, 2004). Participation in student government is done through a student government course, in which students learn leadership and decision-making skills.

In Cyprus, Menon (2005) conducted a study on the views of students regarding the extent of their participation in the management of their university and their satisfaction with the degree of this participation. The study respondents included 135 students of the University of Cyprus. The study found out that students believed that their involvement in the management of their institution was very limited. This resulted in feelings of frustration and dissatisfaction among students, with the majority of 
respondents demanding a higher level of participation in various decision making situations. Menon (2005) proposed that educational institutions abandon outdated leadership models, and adopt measures for increasing student participation in governance.

In Nigeria, Akomolafe and Ibijola (2011) conducted a study on students' participation in university governance and the organizational effectiveness. The study adopted a descriptive research design and data was collected from 500 students and 200 members of staff by the use of a questionnaire. The study established a significant relationship between students' participation in governance and organizational effectiveness in the university system. These researchers concluded that students' participation in governance is an important factor in organizational effectiveness.

In Kenya, Mule (2011) conducted a study on factors influencing students' leaders' involvement in governance of public secondary schools in Mwala District. The study adopted a descriptive survey design and the study participants included principals and 255 student leaders. The study found out that all principals are aware of the importance of participatory school management as a way of governance. The study revealed that there was no significant difference between principals' education level and students' leaders' involvement in public secondary schools; meaning principals across the sampled schools involved students in school governance issues to some extent irrespective of their age. The study further established that there was no significant difference between level of students' involvement in school governance and principals' administration experience. From the above findings it is evident that incorporation of stakeholders in decision making goes a long way in creating an enabling environment for learning and realizing organizational effectiveness.

In Kenya, schools are operating either under the prefectorial system or the students' council system (Mwangi, 2006). In some schools students are given opportunities to select their prefects while in others prefects are appointed by teachers and the school administration. Previous research by Mwangi (2006) and Mulwa (2004) have shown that failure by school administrators to involve students in selection of prefects contributes to strikes and indiscipline in Kenyan schools.

Over the last few years there have been increased calls for increasing the extent of inclusion of students in decision making in secondary schools in Kenya owing to the frequent occurrences of student unrests in the sector (Mwangi, 2006). The call for inclusion of students in the decision-making structure in schools has led to attempts by the Ministry of Education to put in place structures for inclusion (Tikoko \& Kiprop, 2011). The Ministry of Education, with support from UNICEF, introduced the Kenya Secondary 
School Student Council system in 2009 with a view to making secondary school governance more participatory.

Establishment of school governance in secondary schools was faced with challenges, such as conflicting interests of the students and tension between students and the administration (Yuen and Leung 2010). These challenges surfaced when the school became more established, grew in size, took in more students, moved into a bigger campus, and subsequently needed to face the public examinations. Understanding such factors will enable school administrators to effectively institutionalize student participation, such as forming student council. Student council often serves to engage student in learning about democracy and leadership.

According to Fadhili (2005), most students and teachers attribute indiscipline to lack of dialogue between the administrators and the students. Most headteachers adopt master/servant, superior/inferior attitude in dealing with students. They rarely listen to students ${ }^{\text {ee }}$ grievances because they believe that they have nothing to offer. This creates a lot of tension, stress and misunderstanding. It eventually leads to frustration and violence as manifested in strikes. Opportunities should be provided where teachers, students, and administrators can sit down and discuss issues affecting their school freely without inhibition, intimidation or victimization. One of the issues identified as a cause of unrest is the lack of communication between the headteachers, teachers, and students.

In view of this, headteachers are required to cultivate a democratic and participatory environment in the school and encourage regular fora (barazas) where teachers and students are encouraged to express their views (MOEST, 2001). This can also be done through the use of suggestion boxes, school assemblies, house meetings, class meetings, guidance and counseling sessions and open days for public and students to encourage collaborative management of the schools (MOEST, 2004, MOEST, 2000/2001). Prompt

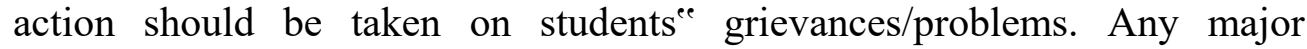
institutional policy change affecting students such as school uniform, diet, school fees, etc. must be done in consultation with the Board of Management, Parent Association and the students.

\section{Statement of the Problem}

As students from various socio-economic backgrounds meet in the school environment, the need to observe rules and regulations becomes imperative so that order, discipline, and conducive learning environment may be created (Blandford, 1998). Over the last few years there have been increased calls for increasing the extent of inclusion of students in decision making in secondary schools in Kenya owing to frequent occurrence of 
students unrests in the sector (kamuhanda, 2003; Buhere 2008; kindiki 2009).

Afullo (2005) noted that students' unrests have become a major concern in schools. Afullo further revealed that Kenyan teachers are continuously finding it difficult to enforce discipline particularly after the abolishment of corporal punishment by the Kenyan government in 2003 since discipline is often equated with corporal punishment. These manifestations, among others, are an indicator of prevalence of indiscipline in our public schools, despite the introduction of alternative measures of discipline management. Ideally, effective discipline is primarily a matter of instruction. These include preventions and intervention programs and strategies for changing student behavior, and educating and involving and supporting stakeholders. Effective discipline relies on empirical evidence rather than custom or habit.

According to the Sub-County Education Office's report (2013), many secondary schools in Teso- North Sub County have not scored well on discipline, and the reasons given for these is lack of students' involvement. This has been blamed for poor academic performance in National examination, strikes, early pregnancies, destruction of property and drug abuse. Arising number of students from these schools are becoming more unruly. This might be an indicator that the current methods of discipline management are not effective in managing students' discipline. Being reflective of the overall situation in the whole country, this study therefore sought to investigate if student council participation in management of discipline helps improve students’ discipline.

\section{Objectives of the Study.}

i. To establish the influence of student council participation in the periodic review of rules and regulations on management of discipline.

ii. To determine the influence of student council involvement in designing punishment on the management of discipline.

\section{Research design and methodogy.}

This study was conducted through descriptive survey design. This is a research design where the researcher describes the state of affairs as it is and reports the findings Kombo and Tromp (2009). The design would enable the researcher to consider issues such as economy of the design, rapid data collection and ability to understand population from a part of it. The design is also suitable for extensive research. The survey research design generally entails present oriented methodology. It is used to investigate by selecting samples for analyses and discover occurrences. For the purpose of the study, the descriptive survey design would provide qualitative and numeric 
description of some of the population /student and describe and explain occurrences. They are flexible, as questions can be asked on range of subject in one questionnaire, and analysis can yield unexpected insights into the population being studied.

The study was conducted in Teso North Sub-County Busia County Western Kenya. The secondary schools were grouped as extra-county, county and sub-county schools. They were grouped further as single sex, mixed day, mixed day and boarding. Teso North Sub-County has the longest experience of indiscipline cases among all sub-counties in Busia County among the public secondary schools according Ministry of Education records. It was therefore considered appropriate for providing an ideal point for the study.

The target population was 27 principals, 189 teachers (132 male and 57 females) and 7379 students (3524 boys and 3855 girls); according to the Sub-County Education Office's report (2014).This study employed stratified sampling techniques. A stratified sampling technique was used to select the schools and the category of respondents to be included in this sample.

The sample size consisted of 365 students from 9 public secondary schools. This sample size was determined using Krejcie and Morgans (1990) table of sample determination. The students were stratified into two subgroups, that is, those who hold leadership position and those who do not hold any leadership position. Simple random sampling technique was then used to select 180 student leaders and 185 students who held no post in the selected schools. Random sampling technique was used on the category of respondents due to the fact that the population being sampled was heterogeneous in nature (Serem 2013). On the other hand, two teachers were selected from each school giving a sample size of 18 teachers.

In teachers, the sampling strategy used was purposive sampling.

The researcher used questionnaires, interviews and document analysis as the main tools for collecting data. The selection of these tools was guided by the nature of data to be collected, the time available as well as by the objectives of the study.

Data collected was analyzed using descriptive statistics. Analysis of data was done using the Statistical Package for Social Sciences (SPSS) program. The means, frequencies and percentages was used in analyzing data and interpreting the respondents' perception on issues raised from the questionnaire for research questions to be answered. Percentages and frequencies were used because it is easy to communicate the research findings of the data, (Mugenda and Mugenda, 1999). Descriptive analysis was appropriate for the study because it involved descriptions, analysis and interpretations of circumstances prevailing at the time of the study. Frequency tables, pie charts and graphs were used to illustrate and interpret 
information related to study. The major ethical problem in this study is the anonymity of the respondents. Obtaining a valid sample will entail interacting with respondents to interview them and asking them to fill questionnaire which in itself will expose them and therefore infringement on their anonymity. However the respondents will be assured their confidentiality by not writing their names.

\section{Findings and Discussion.}

\section{Influence of Student Council Participation in the Periodic Review of Rules and Regulations on Management of Discipline.}

The study established that students' involvement in the review of rules and regulations had positive influence on students' discipline. However it emerged that the students were not fully involved in the periodic review of rules and regulation. They even scored less than fifty percent in some listed statements measuring their involvement. These statements included: rules and regulation is usually negotiated, and applies to particular conditions and problems in this school; rules and regulation is always applied in affair, consistent and just manner; students are always in the right school uniform as shown in table 3.1.

Table 3.1. Respondents' involvement in the review of rules and regulations.

\begin{tabular}{|c|c|c|c|c|c|c|}
\hline \multirow{2}{*}{ Statements } & \multicolumn{2}{|c|}{ Disagree n (\%) } & \multicolumn{2}{c|}{ Undecided $\mathrm{n}(\%)$} & \multicolumn{2}{c|}{ Agree n (\%) } \\
\cline { 2 - 7 } & Students & Teachers & Students & Teachers & Students & Teachers \\
\hline $\begin{array}{c}\text { Students in } \\
\text { school identify } \\
\text { with rules and } \\
\text { regulation }\end{array}$ & $50(14.84)$ & $2(14.29)$ & $15(4.45)$ & $1(7.14)$ & $272(80.71)$ & $11(78.57)$ \\
\hline $\begin{array}{c}\text { Rules and } \\
\text { regulation is } \\
\text { usually } \\
\text { negotiated and } \\
\text { applies to } \\
\text { particular } \\
\text { conditions and } \\
\text { problems in } \\
\text { this school }\end{array}$ & $139(41.25)$ & $9(64.29)$ & $25(7.37)$ & $0(0)$ & $175(51.93)$ & $5(35.71)$ \\
\hline $\begin{array}{c}\text { Rules and } \\
\text { regulation is } \\
\text { always applied } \\
\text { in affair, } \\
\text { consistent and } \\
\text { just manner }\end{array}$ & $160(47.48)$ & $1(7.14)$ & $27(7.99)$ & $0(0)$ & $195(57.86)$ & $13(92.86)$ \\
\hline $\begin{array}{c}\text { Students are } \\
\text { obedient and } \\
\text { respectful to } \\
\text { stipulated rules } \\
\text { and regulation }\end{array}$ & $74(21.96)$ & $1(7.14)$ & $24(7.08)$ & $3(21.43)$ & $241(71.51)$ & $10(71.43)$ \\
\hline
\end{tabular}




\begin{tabular}{|c|c|c|c|c|c|c|}
\hline $\begin{array}{l}\text { since they are } \\
\text { involved. }\end{array}$ & & & & & & \\
\hline $\begin{array}{l}\text { Students } \\
\text { observe } \\
\text { punctuality in } \\
\text { school } \\
\text { programs and } \\
\text { schedules } \\
\text { because they } \\
\text { own it. }\end{array}$ & 74(21.96) & $0(0)$ & $18(5.49)$ & $0(0)$ & $236(70.03)$ & $14(100)$ \\
\hline $\begin{array}{l}\text { Parents support } \\
\text { school rules } \\
\text { and regulation } \\
\text { by ensuring } \\
\text { their children } \\
\text { observe it. }\end{array}$ & $73(21.66)$ & $1(7.14)$ & $38(11.28)$ & $3(21.43)$ & $226(67.06)$ & $10(71.43)$ \\
\hline $\begin{array}{c}\text { Students attend } \\
\text { all classes and } \\
\text { do all exams } \\
\text { because it is } \\
\text { part of rules } \\
\text { and regulation } \\
\text { they help } \\
\text { formulate. }\end{array}$ & $136(40.36)$ & $3(21.43)$ & 12(3.61) & $3(21.43)$ & $184(54.60)$ & $8(57.14)$ \\
\hline $\begin{array}{l}\text { Students are } \\
\text { always in } \\
\text { school as is } \\
\text { part of rules } \\
\text { and regulation } \\
\text { they help } \\
\text { formulate. }\end{array}$ & $120(35.61)$ & $0(0)$ & $25(7.55)$ & $4(28.57)$ & 183(54.30) & $9(64.29)$ \\
\hline $\begin{array}{l}\text { Students are } \\
\text { always in the } \\
\text { right school } \\
\text { uniform } \\
\text { because it is } \\
\text { part of rules } \\
\text { they help } \\
\text { formulate. }\end{array}$ & 108(32.05) & $0(0)$ & $16(4.75)$ & $5(35.71)$ & 213(63.20) & $9(64.29)$ \\
\hline
\end{tabular}

Responses from principal interviews revealed that rules and regulations are rarely revised and in most cases all stakeholders are not fully involved especially students. The study further revealed common disciplinary problems experienced in schools in Teso North Sub- County and their possible causes as lack of students' involvement. 


\section{Influence of Student Council Involvement in Designing Punishment in the Management of Discipline.}

In relation to the influence of student council involvement in designing punishment, the responses indicated that schools partially involved students in making administrative rules pertaining to the discipline of the students and to prescribe appropriate punishment for breach or nonadherence to such rules. However all the respondents revealed that students do not take punishment positively at any time as indicated by their scores. This could be because may be punishment is not always applied in affair, consistent and just manner or may be students are never involved in designing punishment as claimed. The study further revealed that common disciplinary problems experienced in school were due unilateral decisions made by school management that students felt infringed on their rights. The responses are shown in table 3.2.

Table 5.2. Respondents' involvement in the designing punishment.

\begin{tabular}{|c|c|c|c|c|c|c|}
\hline \multirow[t]{2}{*}{ Statements } & \multicolumn{2}{|c|}{ Disagree n (\%) } & \multicolumn{2}{|c|}{ Undecided n (\%) } & \multicolumn{2}{|c|}{ Agree n (\%) } \\
\hline & Students & Teachers & Students & Teachers & Students & Teachers \\
\hline $\begin{array}{l}\text { Punishment is } \\
\text { usually } \\
\text { negotiated , and } \\
\text { applies to } \\
\text { particular } \\
\text { conditions and } \\
\text { problems in this } \\
\text { school }\end{array}$ & $\begin{array}{c}113(33.5 \\
3)\end{array}$ & $10(71.43)$ & $20(5.93)$ & $0(0)$ & $204(60.54)$ & $4(28.57)$ \\
\hline $\begin{array}{l}\text { Punishment is } \\
\text { always applied } \\
\text { in affair, } \\
\text { consistent and } \\
\text { just manner }\end{array}$ & $\begin{array}{c}134(39.7 \\
6)\end{array}$ & $2(14.29)$ & $23(6.82)$ & $0(0)$ & $180(53.41)$ & $12(85.71)$ \\
\hline $\begin{array}{l}\text { Punishment } \\
\text { overrides use of } \\
\text { rewards in } \\
\text { disciplining } \\
\text { students }\end{array}$ & $\begin{array}{c}152(45.1 \\
0)\end{array}$ & $14(100)$ & 55(16.32) & $0(0)$ & $130(38.58)$ & $0(0)$ \\
\hline $\begin{array}{l}\text { Punishment } \\
\text { ensures } \\
\text { orderliness } \\
\text { among the } \\
\text { students }\end{array}$ & $\begin{array}{c}73(21.66 \\
)\end{array}$ & $1(7.14)$ & $18(5.34)$ & $2(14.29)$ & $246(73.00)$ & 11(78.57) \\
\hline $\begin{array}{l}\text { Students accept } \\
\text { punishment if } \\
\text { they fail to } \\
\text { comply with } \\
\text { school rules and } \\
\text { regulation }\end{array}$ & $33(9.79)$ & $3(21.43)$ & $13(3.86)$ & $2(14.29)$ & 281(83.38) & $9(64.29)$ \\
\hline Teachers are & $130(38.5$ & $1(7.14)$ & $28(8.61)$ & $0(0)$ & 179(53.12) & $13(92.86)$ \\
\hline
\end{tabular}




\begin{tabular}{|c|c|c|c|c|c|c|}
\hline $\begin{array}{c}\text { fair when } \\
\text { administering } \\
\text { punishment }\end{array}$ & 8) & & & & & \\
\hline $\begin{array}{c}\text { Students are } \\
\text { only punished } \\
\text { for mistakes } \\
\text { done }\end{array}$ & $\begin{array}{c}97(28.78 \\
)\end{array}$ & $1(7.14)$ & $15(4.45)$ & $0(0)$ & 225(66.77) & $13(92.86)$ \\
\hline $\begin{array}{l}\text { Students take } \\
\text { punishment } \\
\text { positively at } \\
\text { any time }\end{array}$ & $\begin{array}{c}156(46.2 \\
9)\end{array}$ & $4(28.57)$ & $29(8.61)$ & $7(50.00)$ & $152(45.10)$ & $3(21.43)$ \\
\hline $\begin{array}{l}\text { There are } \\
\text { various } \\
\text { alternative } \\
\text { forms of } \\
\text { punishment in } \\
\text { this school }\end{array}$ & $\begin{array}{c}\text { 73(21.66 } \\
\text { ) }\end{array}$ & $0(0)$ & $14(4.15)$ & $0(0)$ & $250(74.18)$ & $14(100)$ \\
\hline $\begin{array}{l}\text { All teachers } \\
\text { punish students } \\
\text { in this school }\end{array}$ & $\begin{array}{c}132(39.1 \\
7)\end{array}$ & $3(21.43)$ & $22(6.53)$ & $0(0)$ & 183(54.30) & 11(78.57) \\
\hline
\end{tabular}

\section{Conclusion}

In general, the study established that students were partially involved in the management of discipline. Partial involvement of students in governance can be attributed to the educators' attitude towards the students who seem not to be serious, they also lack understanding, they are treated with suspicion and the educators have fears in involving them in school management of discipline. This implies that despite majority of the educators viewing the process of involving students in school management as crucial, a notable number of them felt that students did not have key role to play on issues related to discipline.

Generally, the success of the school depends on how each stakeholder (students, teachers, principal and parents) are handled and participated in the management of discipline process. This means that absence of students in the management of discipline may hamper decisions made by other stakeholders hence making them ineffective.

\section{Recommendation.}

i. The research found out that students are not fully involved in review of rules and regulation. The study therefore recommends that schools should fully involve students' in school management of discipline. They should empower students' council in which students' views and ideas can be heard and discussed. The council should be known to all students and well informed in terms of school policies and should have a say on important issues. 
ii. The research found out that the students do not take punishment positively at any time. The study therefore recommends that the schools should be encouraged to use alternative methods of discipline management rather than punishment. This may include methods such as guidance and counseling, use of rewards among others.

\section{References:}

1. Akomolafe, C.O \& Ibijola, E.Y (2011). Students' participation in university governance and organizational effectiveness in Ekiti and Ondo states, Nigeria. American Journal of Social and Management Sciences, 2(2): 231-236.

2. Bäckman, E. \& Trafford, B. (2007). Democratic governance of schools. Council of

3. EuropePublishing,Accessedfrom:http://tandis.odihr.pl/documents/hre compendium/en/CD\%20SEC\%202\%20ENV/PARTNERS\%20RESO URCES/CoE\%20DemocraticGovernanceSchools\%20ENG.pdf

4. Blandford, S. (1998). Managing Discipline in Schools. London: Routledge.

5. Buhere.k. (2008, July 21).Boarding Schools not Cause of Riots. Daily Nation p.4.Nairobi: Nation Media.

6. Fadhili, W. (2005, September 23). Indiscipline in Schools. Who is to Blame? The Standard, p. 10. Nairobi: The Standard Group Page 138

7. Kamuhanda.B.(2003). Students Power in Africa's Higher Education. A case of Makerere University Kampala CRC publishers.

8. Kindiki, J. N. (2009). Effectiveness of boards of governors in curriculum Implementation in secondary schools in Kenya .Educational Research and Review,4(5): 260-266.

9. Kombo, D.K and Tromp, D.L (2009). Proposals and Thesis Writing, An Introduction. Nairobi: Don Bosco Printing press.

10. Krejcie,R.V., \& Morgan, D. W.,(1970).Determining Sample Size for Research Activities. Educational and psychological measurement. The NEA Research Bulletin,Vol.38.

11. Menon, M. E. (2005). Students' Views Regarding their Participation in University Governance: Implications for Distributed Leadership in Higher Education. Tertiary Education and Management Volume 11, Issue 2, [11(2)] pp. 167

12. Miller, J. J. (2004). Involving students in governance: Citizenship education policy brief. Denver, CO: Education Commission of the States.

13. Ministry of Education Science and Technology (MOEST) (2001).Press Statement by Minister for Education Hon. Henry 
Kosgei E.G.H, M.P. on the Release of The Report on Student Discipline and Unrest in Kenyan Secondary Schools. Unpublished Report, Office of the Minister, Nairobi. September 25, 2001.

14. Ministry of Education Science and Technology (MOEST) (2004a). Report on School Unrest in Rift valley Province. Ref: PDE/RV/9/155 dated July 20, 2004. .Unpublished Report, Provincial Director of Education, Nakuru.

15. Mugenda O. M. \& Mugenda, G. A. (1999). Research methodsQuantitative and

Qualitative Approaches, Acts Press, Nairobi.

16. Mule, M. J. (2011). Factors influencing student leaders' involvement in governance of Public secondary schools in Mwala district, Kenya. Unpublished Med Thesis University of Nairobi.

17. Mulwa, D. (2004). Secondary school students' involvement in decision making in Mwala Division of Machakos District. Unpublished MED Thesis, Kenyatta University, Nairobi.

18. Mwangi, J. M. (2006). An investigation of the effectiveness of prefects in maintaining discipline in public secondary schools in Kalou Division of Nyandarua District. Unpublished M.Ed. Project, Kenyatta University.

19. Ministry of Education Science and Technology (MOEST) (2000/2001).Report on Causes Effects and Remedies of Indiscipline in Secondary Schools in Central Province. . Nairobi: Government printers.

20. Neigel, K. A. (2006). Building leadership capacity in students. Principal Leadership, 7(4): 20-24

21. Serem D.K. Boit J .M. \& Wanyama M.N. (2013, Understanding Research, a simplified. form: Utafiti foundation- Kenya.

22. Tikoko, J. B. \& Kiprop, C. J. (2011). Extent of student participation in decision making. in secondary schools in Kenya. International Journal of Humanities and Social Science, 1(21): 92-99.

23. Yuen, T. W., \& Leung, Y. W. (2010). Engaging students in school governance: A case study of the challenges and the way forward. International Studies in Educational Administration, 38(3): 57-79. 